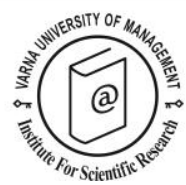

Examining the Tourism-Led Growth Hypothesis,

\title{
Agricultural-Led Growth Hypothesis and Economic Growth in Top Agricultural Producing Economies
}

\author{
Mfonobong Udom Etokakpan ${ }^{1}$ Festus Victor Bekun ${ }^{2}$ and \\ A. Mohammed Abubakar ${ }^{*}$
}

Received: 27/07/2018 Accepted: 05/09/2018

\footnotetext{
1 Department of Economics, Famagusta, Eastern Mediterranean University, North Cyprus, via Mersin 10, Turkey, Economics Department, Babcock University, Ogun State, Nigeria. E-mail: etokakpanmfonudom@yahoo.com

2 Institute of Graduate Studies and Research Faculty of Business and Economics, Department of Economics, Famagusta, Eastern Mediterranean University, North Cyprus, via Mersin 10, Turkey. E-mail: festus.bekun@emu.edu.tr

${ }^{3}$ College of Business Antalya Bilim University, Turkey. E-mail: mohammed.abubakar@antalya.edu.tr

* Corresponding author
}

\begin{abstract}
Most nations are striving to achieve sustainable economic growth. Among the diverse routes explored are tourism and agriculture. This study examines tourism-led growth hypothesis and agriculture-induced growth hypothesis in the context of the world top four agricultural producing economies in a multivariate balanced panel framework between 1995 and 2015. The findings from the bootstrap panel co-integration tests do not support a long-run relationship among the variables. Subsequently, causality test reveals a feedback relationship between international tourism receipt and economic growth. Thus, the tourism-led growth hypothesis is affirmed, while a uni-directional causality runs from agriculture to economic growth. Our findings affirm both the tourism-led and agriculture-led growth hypotheses. Hence, tourism and agriculture sectors are twin growth catalysts in the selected states, that is, both tourism and agriculture sectors have complementary effect on economic growth in the bloc investigated.
\end{abstract}

(C) 2019 Varna University of Management. All rights reserved

Keywords: Tourism-led growth hypothesis, Agricultural-led growth hypothesis, Panel data econometrics

Citation: Etokakpan, M., F. Bekun and A. Abubakar (2019) Examining the Tourism-Led Growth Hypothesis, Agricultural-Led Growth Hypothesis and Economic Growth in Top Agricultural Producing Economies. European Journal of Tourism Research 21, pp. 132-137

\section{Introduction}

Tourism has been one of the fastest-growing industries globally, primarily due to its uninterrupted growth in the past decades. Despite occasional shocks and financial crises, the industry has grown over time, 
demonstrating its strength and resilience. The tourism industry forms an integral part of socioeconomic progress both in developing and developed economies through its inherent ability to create jobs, facilitate enterprise startups, generate export revenues, and promote infrastructural development (Liu \& Song, 2018).

The tourism-led growth hypothesis (TLGH) is well documented in the tourism economics literature. The seminal study of Balaguer and Cantavella-Jorda (2002), where the pertinent role of tourism in the Spanish economy was empirically explored, served as an invitation to numerous studies (see Yildirim \& Ocal, 2004; Campos \& Sequeira, 2005; Yorucu \& Mehmet, 2011; Akadiri et al., 2017; Alola \& Alola, 2018; Roudi et al., 2018; Sokhanvar et al., 2018). However, there has been no consensus among scholars in their findings. It is on this premise that this study seeks to explore if the TLGH holds for the top agricultural producing countries.

This study aims to empirically address the above-mentioned objective since a study that provides a clear insight into TLGH in top agricultural producing countries will be of interest to both policy and decision makers. Besides, a more robust understanding of this interplay with other contextual factors will guide future TLGH implementation. Extant empirical studies on TLGH have not only extensively explored the causal linkage between tourism receipts and economic growth, but also between tourism receipts and other macroeconomic variables (see Tang et al., 2007; Akinboade \& Braimoh, 2010; Husein \&
Kara, 2011; Amaghionyeodiwe, 2012; Brida et al., 2016).

The knowledge gaps this study seeks to fill can be classified by scope of analysis and econometric techniques applied. First, we test the TLGH by focusing the scope on a bloc of four large agricultural producing economies reputed for exportation of agricultural commodities (Brazil, Russia, China and the United States, hereafter collectively referred to as BRCU). Second, we seek to verify simultaneously if the twin-growth driverstourism and agriculture-spur economic growth in the long-run. Third, we utilize the secondgeneration panel approach which adequately deals with the challenges posed by countryspecific heterogeneity and cross-sectional dependency.

The countries under investigation represent the top three agricultural producing economies and are also the largest exporters of agricultural commodities in the emerging markets, while the United States is included as the largest exporter of agricultural commodities in the world. Therefore, the combined analysis of these two groups of countries allows us to test for the validity of tourism-led and agriculture-led growth models in the agricultural producing states.

The rest of the paper proceeds as follows; section 2 discusses the data and methodology, section 3 presents the results and discussion, and finally, section 4 concludes the study.

\section{Data and Methodology}

To test the TLGH, the time dimension is made

Table 1. Variable description and data source

\begin{tabular}{|c|c|c|c|}
\hline Variable name & Symbol & Description & Data Source \\
\hline $\begin{array}{l}\text { Gross domestic } \\
\text { product }\end{array}$ & RGDP & Real gross domestic product in constant 2010 USD. & $\begin{array}{l}\text { World development } \\
\text { indicator }\end{array}$ \\
\hline $\begin{array}{l}\text { Agricultural } \\
\text { value added }\end{array}$ & AVA & $\begin{array}{l}\text { All output from agricultural subsector namely, crop } \\
\text { production, husbandry, fishery and livestock. }\end{array}$ & $\begin{array}{l}\text { World development } \\
\text { indicator }\end{array}$ \\
\hline $\begin{array}{l}\text { Effective } \\
\text { exchange rate }\end{array}$ & EXR & $\begin{array}{l}\text { The value of a currency against an allotted weighted } \\
\text { average of several foreign currencies divided by a price } \\
\text { deflator or cost index. } \\
\text { The expenditure by international inbound visitors, }\end{array}$ & $\begin{array}{l}\text { World development } \\
\text { indicator }\end{array}$ \\
\hline $\begin{array}{l}\text { International } \\
\text { tourism receipt }\end{array}$ & TR & $\begin{array}{l}\text { including payment to national carriers for international } \\
\text { transport }\end{array}$ & $\begin{array}{l}\text { World development } \\
\text { indicator }\end{array}$ \\
\hline
\end{tabular}


up of annual data covering the period from 1995 to 2015, while the cross-sectional dimension consists of Brazil, Russia, China and the United States (BRCU). The data was retrieved from the World Bank development indicators (https://data.worldbank.org/indicator), and detailed explanation of choice variables is rendered below.

This study's empirical route proceeds in four stages. First, test for cross sectional dependency (CSD) is conducted to establish whether or not common shock effect exists in the data series. This is done to avoid spurious analysis that could arise from wrongly assuming cross-sectional independency. To achieve this, the study employs the BreuschPagan (1980) LM test, the Pesaran (2004) Scaled LM test, and the Pesaran (2004) CD test. Second, stationarity testing is carried out to ascertain the order of integration and asymptotic properties of the variables under consideration. To this end, the cross-sectionally augmented IPS (Im et al., 2003) panel unit root tests of Pesaran (2007) is conducted. Third, the existence of a long-run relationship between the variables is tested through the Westerlund (2007) panel co-integration test with bootstrapping. This particular cointegration test provides efficient and reliable coefficients, standard errors and confidence intervals even in the presence of CSD. Fourth, the determination of direction of flow of causality is achieved via the heterogeneous non-causality Dimitrescu and Hurlin (2012) approach.

\section{Results and discussions}

The results from the first stage of the empirical analysis (tests for cross-sectional dependence) are reported in Table 2 . The results mainly reject the null hypothesis of cross-sectional independence and confirm the presence of CSD. Thus, we infer interdependence among BRCU countries. The need to account for CSD in subsequent studies in order to circumvent spurious analysis is therefore confirmed.

Next, panel unit root testing as proposed by Pesaran (2007) is executed and the outcomes are reported in Table 3 . For the stationarity test, the null hypothesis of unit root could not be rejected at level for the variables. However,

Table 2. Cross-sectional dependency test for the entire model

\begin{tabular}{llll}
\hline Test & Statistic & d.f. & Prob. \\
\hline Breusch-Pagan LM & 21.41660 & 6 & 0.0015 \\
Pesaran scaled LM & 3.295689 & & 0.0010 \\
Pesaran CD & -0.681936 & & 0.4953 \\
\hline Note: null states cross sectional independence $C D \sim N(0,1)$ & &
\end{tabular}

Note: null states cross sectional independence $C D \sim N(0,1)$

Table 3. Pesaran (2007) unit root test after differencing

\begin{tabular}{lllll}
\hline Variable & CIPS Statistics & \multicolumn{3}{c}{ Critical values (\%) } \\
\hline Rgdp & & 1 & 5 & 10 \\
Tr & -1.423 & 2.51 & 2.25 & 2.12 \\
Ava & -1.921 & 2.51 & 2.25 & 2.12 \\
Exr & -1.955 & 2.51 & 2.25 & 2.12 \\
\hline
\end{tabular}

Note: All variables were non-stationary at level.

Table 4. Westerlund (2007) bootstrapping cointegration test

\begin{tabular}{lllll}
\hline Statistic & Value & Z-value & P-value & Robust P-value \\
\hline $\mathrm{G}_{\mathrm{t}}$ & -0.493 & 5.077 & 1.000 & 0.978 \\
$\mathrm{G}_{\mathrm{a}}$ & -2.587 & 3.221 & 0.999 & 0.878 \\
$\mathrm{P}_{\mathrm{t}}$ & 1.176 & 6.484 & 1.000 & 0.990 \\
$\mathrm{~Pa}$ & 1.446 & 3.575 & 1.000 & 0.993 \\
\hline
\end{tabular}

Note: null of no cointegration with significance level of $0.01,0.05$ and 0.10 respectively. $G_{t}$ and $G_{a}$ test the cointegration for each country individually, and the $P_{a}$ and $P_{t}$ test cointegration of the panel as a whole. 
after first differencing, the null of unit root was rejected in all the variables. Thus, the variables are integrated of order one i.e.(1). It is essential to conduct unit root tests in order to avoid spurious regression, and by extension, erroneous inferences.

The study further proceeds to investigating the long-run relationship (if any) among the variables under review. It is noteworthy that the so-called first-generation cointegration tests are inconsistent in the presence of CSD. This research study therefore relies on secondgeneration panel cointegration testing as proposed by Westerlund (2007). The test is able to accommodate slope heterogeneity and interdependence within the cross-sections under a null specification of no cointegration. Table 4 reports the panel cointegration test results. Based on the test outcomes, the null of no cointegration could not be rejected even at $10 \%$ significance level in all the cases. We therefore find no evidence in support of a longrun relationship between the variables under review.

Finally, this study applies the Dumitrescu-Hurlin (2012) Granger causality test to detect causal relationships among the variables. As shown in Table 5, causality relationship runs from international tourism receipts to economic growth, thus validating the tourism-led growth hypothesis for the bloc of countries under consideration. The dynamic causality also reveals a uni-directional causality running from agricultural production to economic growth, hence validating the agricultural-induced growth hypothesis. That is, in this bloc of countries, the agricultural sector contributes to national prosperity.

\section{Conclusion}

This study employs second-generation panel estimation techniques to examine TLGH in top agricultural producing economies while controlling for effective exchange rate. The study period is from 1995 to 2015.

To ascertain the effectiveness of our analysis, we accounted for CSD and stationarity properties of the variables under consideration. The cointegration test showed and established the presence no conitegration. The causality test further showed a bi-directional causality running from international tourism receipt and economic growth, thus affirming the TLGH. This is in line with the findings of Brida and Risso (2009), Brida et al. (2011), Katircioglu (2014), Koutsouris et al. (2014), and Brida et al. (2016).

Our study also validates the agriculture-led growth hypothesis (ALGH). This reinstates the importance of agriculture to economic growth in the sampled countries. This finding corroborates the conclusion reached by Sertoglu et al. (2017) that agriculture is considered as panacea for long-term economic growth. The reason for the validity of TLGH in the bloc of selected top agricultural producing economies could be because these states are also exporters of agricultural produce. These

Table 5. Panel causality test (Dumitrescu and Hurlin)

\begin{tabular}{lllll}
\hline Null hypothesis & W-stat & Zbar-stat & P-value & Causality \\
\hline tr $\neq>$ rgdp & 4.5849 & 5.0698 & 0.0000 & Yes \\
ava $\neq>$ rgdp & 5.2213 & 5.9698 & 0.0000 & Yes \\
exr $\neq>$ rgdp & 6.0706 & 7.1710 & 0.0000 & Yes \\
rgdp $\neq>$ tr & 0.0000 & -1.4142 & 0.0001 & Yes \\
ava $\neq$ tr & 3.7477 & 3.8859 & 0.8914 & No \\
exr $\neq>$ tr & 2.6472 & 2.3295 & 0.0198 & Yes \\
rgdp $\neq>$ ava & 0.0000 & -1.4142 & 0.1573 & No \\
tr $\neq>$ ava & 1.3511 & 0.4965 & 0.6196 & No \\
exr $\neq>$ ava & 2.0381 & 1.4681 & 0.1421 & No \\
rgdp $\neq>$ exr & 0.0000 & -1.4142 & 0.1573 & No \\
tr $\neq>$ exr & 4.0358 & 4.2933 & 0.0000 & Yes \\
ava $\neq>$ exr & 2.2824 & 1.8137 & 0.0697 & Yes \\
\hline
\end{tabular}

Note: the symbol $\neq>$ signifies that the variables do not Granger cause one another, difference data are used for the causalitv. 
twin factors (tourism and agriculture) are revealed as significant growth catalysts in the selected states. This affirms the finding of Torres (2002, 2003).

Also insightful from the causality test was the unidirectional causal effect running from agricultural production to economic growth. This supports the fact that tourism alone may not be sufficient to sustain economic growth. The above revelation affirms that both tourism and agriculture sectors have complementary rather than substitutive effect on economic growth in the bloc of countries reviewed. This study therefore also strongly recommends that policy makers and stakeholders should adopt long-term policy strategies and policy mix that aid development in both agricultural and tourism sectors.

Several decades of TLGH research has advanced the knowledge base of how tourism shapes and develops the economy. However, there is limited knowledge on how tourism and agriculture interact to foster economic growth. Although a handful of studies have explored TLGH, a clear understanding of TLGH from the perspective of top agricultural producing states is largely lacking. In this sense, we believe that our research is especially timely in the aftermath of the global financial crisis of 2007 2009.

\section{References}

Akadiri, S. S., Akadiri, A. C., \& Alola, U. V. (2017). Is there growth impact of tourism? Evidence from selected small island states. Current Issues in Tourism, 1-19.

Akinboade, O., \& Braimoh, L. A. (2010). International tourism and economic development in South Africa: A Granger causality test. International Journal of Tourism Research, 12, 149-163.

Alola, A. A., \& Alola, U. V. (2018). Agricultural land usage and tourism impact on renewable energy consumption among Coastline Mediterranean Countries. Energy \& Environment, 1-17.

Amaghionyeodiwe, L. A. (2012). A causality analysis of tourism as a long-run economic growth factor in Jamaica. Tourism Economics, 18(5), 1125-1133.
Balaguer, J., \& Cantavella-Jorda, M. (2002). Tourism as a long-run economic growth factor: The Spanish case. Applied Economics, 34(7), 877-884.

Breusch, T. S., \& Pagan, A. R. (1980). The Lagrange multiplier test and its applications to model specification in econometrics. The Review of Economic Studies, 47(1), 239-253.

Brida, J. G., \& Risso, W. A. (2009). Tourism as a factor of long-run economic growth: An empirical analysis for Chile. European Journal of Tourism Research, 2(2), 178185.

Brida, J. G., Punzo, L. F., \& Risso, W. A. (2011). Tourism as a factor of growth: The case of Brazil. Tourism Economics, 17(6), 1375-1386.

Brida, J. G., Cortes-Jimenez, I., \& Pulina, M. (2016). Has the tourism-led growth hypothesis been validated? A literature review. Current Issues in Tourism, 19(5), 394-430,

DOI:10.1080/13683500.2013.868414

Campos, C. \& Sequeira, T. N. (2005). Tourism and Economic growth: A Panel Data Approach. International conference on Theoretical Advances in Tourism Economics, University of Evora, $18^{\text {th }}-19^{\text {th }}$ March 2005, Portugal.

Dumitrescu, E. I., \& Hurlin, C. (2012). Testing for Granger non-causality in heterogeneous panels. Economic Modelling, 29(4), 1450-1460.

Husein, J., \& Kara, S. M. (2011). Research note: Re-examining the tourism-led growth hypothesis for Turkey. Tourism Economics, 17(4), 917-924.

Im, K. S., Pesaran, M. H., \& Shin, Y. (2003). Testing for Unit Roots in Heterogeneous Panels. Journal of Econometrics, 115(1), 53-74.

Katircioglu, S. T. (2014). International tourism, energy consumption, and environmental pollution: The case of Turkey. Renewable and Sustainable Energy Reviews, 36, 180-187.

Koutsouris, A., Gidarakou, I., Grava, F., \& Michailidis, A. (2014). The phantom of (agri) tourism and agriculture symbiosis? A Greek case study. Tourism Management Perspectives, 12, 94-103 
Liu, H., \& Song, H. (2018). New Evidence of Dynamic Links between Tourism and Economic Growth Based on MixedFrequency Granger Causality Tests. Journal of Travel Research, 57(7), 899907.

Pesaran, M. H. (2004). General Diagnostic Tests for Cross Section Dependence in Panels. CESIFO Working Paper Series No. 1229; IZA Discussion Paper No. 1240.

Pesaran, M.H. (2007). A simple panel unit root test in the presence of cross-section dependence. Journal of Applied Econometrics, 22(2), 265-312.

Roudi, S., Arasli, H., \& Akadiri, S. S. (2018). New insights into an old issue-examining the influence of tourism on economic growth: evidence from selected small island developing states. Current Issues in Tourism, 1-21.

Sertoglu, K., Ugural, S., \& Bekun, F. V. (2017). The Contribution of Agricultural Sector on Economic Growth of Nigeria. International Journal of Economics and Financial Issues, 7(1):547-552.

Sokhanvar, A., Çiftçioğlu, S., \& Javid, E. (2018). Another look at tourism-economic development nexus. Tourism management perspectives, 26, 97-106.
Tang, S., Selvanathan, E. A., \& Selvanathan, S. (2007). The relationship between foreign direct investment and tourism: Empirical evidence from China. Tourism Economics, 13(1), 25-39.

Torres, R. (2002). Toward a better understanding of tourism and agriculture linkages in the Yucatan: Tourist food consumption and preferences. Tourism Geographies, 4(3), 282-306.

Torres, R. (2003). Linkages between tourism and agriculture in Mexico. Annals of Tourism Research, 30(3), 546-566.

Westerlund, J. (2007). Testing for error correction in panel data. Oxford Bulletin of Economics and statistics, 69(6), 709-748.

World Bank (2017). World Bank Development Indicators database (online). Available at https://data.worldbank.org/

Yildirim, J. \& Ocal, N. (2004). Tourism and Economic growth in Turkey. Ekonomik Yaklasim, 15(52-53), 131-141.

Yorucu, V., \& Mehmet, O. (2011). The boundstest approach for co-integration between international tourist arrivals, per capita income and cost of living: the case of All Cyprus. Applied

Economics Letters, 18(14), 1327-1331. 